медицинскую помощь; обеспечения права на благоприятную окружающую среду; образования.

Из указанного следует, что прокурор не во всех случаях обладает процессуальными полномочиями на обращение в суд в интересах гражданина. Зачастую, по результатам проведенной прокурорской проверки отсутствуют и правовые (материальные) основания на обращение в суд с заявлением.

Таким образом, прокурор, участвуя в судебном разбирательстве по гражданским делам, выступает от лица государства, которое гарантирует защиту основных прав и свобод человека и гражданина. Рассматривая в совокупности ст. 45 и 48 Конституции РФ, можно прийти к выводу о том, что эта форма государственной юридической помощи должна предоставляться по определенным социально значимым делам, по которым государство не может устраниться от участия в силу их общественной значимости. Именно социальная и общественная значимость дела всегда определяла необходимость участия в нем государства, в том числе и через судебную помощь тем лицам, которые в ней нуждаются.

На современном этапе развития государства защита прав граждан не может быть эффективной без активного участия органов прокуратуры в гражданском судопроизводстве, что, в свою очередь, требует повышения роли прокуратуры в обеспечении правозащитной функции в гражданском судопроизводстве и ее четкого закрепления в действующем законодательстве. А также стоит добавить, что участие прокурора в делах, не предусмотренных Гражданским процессуальным кодексом РФ и другими федеральными законами, бесполезно, в связи с отсутствием у прокурора полномочий по последующему оспариванию таких судебных постановлений.

$$
* * *
$$

1. Бессарабов В. Г. Прокурорский надзор : учебник. М., 2006. С. 355.

2. Винокурова Ю.А. Прокурорский надзор : учебник / 8-е изд., перераб. и доп. М., 2008. С. 12.

3. "Гражданский процессуальный кодекс Российской Федерации" от 14.11.2002 N 138-Ф3 (ред. от 01.07.2021) ст.45.

4. Дементеева, И. И. Развитие уголовно-исполнительного законодательства России : специальность 12.00 .08 "Уголовное право и криминология; уголовно-исполнительное право" : автореферат диссертации на соискание ученой степени кандидата юридических наук / Дементеева Ирина Ильинична. - Москва, 2006. $24 \mathrm{c}$

5. $\quad$ Ергашев Е. Р. Принципы прокурорского надзорно-охранительного права. Екатеринбург, 2007. С. 206.

6. Жилин Г А. Цели гражданского судопроизводства и их реализация в суде первой инстанции. М., 2000. С. 214.

7. "Конституция Российской Федерации" (принята всенародным голосованием 12.12.1993 с изменениями, одобренными в ходе общероссийского голосования 01.07.2020) ст. 45-48.

8. Малешин, Д. Я. Методология гражданского процессуального права. М., 2010. С. 104.

9. Осокина Г. А. Гражданский процесс. М., 2003. С. 204.

10. Петров, И. В. Социально-правовая ответственность в предпринимательской деятельности / И. В. Петров, И. И. Дементеева // Национальные экономики в условиях глобальных и локальных трансформаций : Сборник статей международной научно-практической конференции, Москва, 23-28 октября 2018 года / Под ред. Г.Б. Клейнера, Х.А. Константиниди, В.В. Сорокожердьева. - Москва: АНО "Научно-исследовательский институт истории, экономики и права", 2018. - С. 77-80.

\title{
Кетух М.К. \\ Проблемы и особенности использования свидетельских показаний в гражданском процессе
}

Кубанский государственный аграрный университет им. И. Т. Трубилина

(Россия, Краснодар)

doi: 10.18411/trnio-01-2022-173

\section{Аннотация}

В статье приводятся дискуссионные мысли на тему, посвященную проблемам, с которыми приходится сталкиваться всем органам и лицам, участвующим в судебном 
разбирательстве при работе со свидетельскими показаниями, которые могут являться распространенным средством доказывания в гражданском процессе. В ходе рассмотрения особенностей любых дел судопроизводство, как правило, вместе с прочими доказательствами применяет и показания со стороны свидетелей.

В статье дается анализ законодательных норм, исследуются и рассматриваются методы борьбы с лжесвидетельством. В заключении делается вывод о том, что данное средство доказывания следует применять крайне осторожно, так человеческий фактор может повлиять на те или иные аспекты дачи показаний. Поэтому информацию свидетелей нужно сопоставлять с другими средствами доказывания, так как по своей правовой природе данное средство доказывания не бесспорно и зачастую подвергается критике.

Ключевые слова: свидетельские показания, свидетельский иммунитет, гражданский процесс, лжесвидетельство.

\section{Abstract}

The article contains discussion reflections on the topic devoted to the problems that all bodies and persons involved in the case have to face when working with witness testimony. Witness testimony in civil proceedings may be a common means of proof in civil proceedings. In the course of considering the specifics of any cases during the trial, as a rule, along with other evidence, the testimony of witnesses is also used.

The article analyzes the legislative norms, discusses and analyzes methods of combating perjury. In conclusion, it is concluded that this means of proof should be used with extreme caution, since the human factor may affect some aspects of witness testimony. Therefore, information from the testimony of witnesses must be compared with other means of proof, since by its legal nature this means of proof is not indisputable and is often criticized.

Keywords: witness testimony, civil procedural immunity of a witness, perjury.,

В настоящее время, ни гражданское процессуальное, ни арбитражное процессуальное законодательство не содержит определения понятия свидетельские показания. В различные время развития отечественной науки процессуального права, учеными предлагались авторские определения данного понятия. Сейчас же, большинство исследователей соглашаются с дефиницией, предложенной В.В. Молчановым.

Однако несмотря на это свидетельские показания в гражданском процессе являются распространенным средством. В ходе рассмотрения особенностей любых дел судопроизводство, как правило, вместе с прочими доказательствами применяет и показания со стороны свидетелей.

Свидетелем может являться кто угодно, если это физическое лицо. Данное лицо должно располагать какой-то информацией, связанной с делом. Фундаментом свидетельских показаний являются факты, воспринимаемые лично свидетелем.

В соответствии с п. 3 ст. 1 ГК РФ участники гражданских правоотношений обязаны действовать добросовестно в процессе установления, осуществления и защиты гражданских прав и исполнении гражданских обязанностей. Важно, чтобы свидетель как в гражданском процессе, так и в любом другом процессе был юридически не заинтересованным в исходе дела. Лицо, у которого все же есть заинтересованность, может быть привлечен в процесс в качестве другого участника гражданского процесса (например, ответчик, как истец, третье лицо и т.д.).

Согласно части 1 статьи 69 ГПК свидетелем является лицо, которому могут быть известны какие-либо сведения об обстоятельствах, имеющих значение для рассмотрения и разрешения дела.

Показания свидетеля зачастую будут доказательствами по делу. Но не являются доказательствами сведения, данные свидетелем, если он не может или не хочет рассказать откуда у него этот источник информации. 
Свидетели так же могут быть, косвенными жертвами, поскольку свидетельство о преступлении или ситуации насилия могут подорвать авторитет или негативно отразиться на эмоциональном состоянии свидетеля. Если обобщать, то тот, кто является свидетелем, должен давать показания, за исключением некоторых лиц. Это близкие родственники, лица, охваченные профессиональной тайной, таких как журналисты, врачи и адвокаты. Однако возможно исключение, если дело является очень важным, тогда их могут заставить давать показания.

Так же, игнорирование свидетельских показаний, будет является большим нарушением процессуальных норм. Есть определенная группа лиц, которая наделена своеобразной привилегией. Они могу не давать показания - это и называется свидетельским иммунитетом. На самом деле свидетельский иммунитет понятие не новое, оно было известно еще со времен древнего Рима, тогда свидетелями не могли быть малолетние дети.

Сейчас в конституции Российской федерации существует правило, по которому лицо не обязано свидетельствовать против своих близких родственников. Круг таких лиц устанавливается федеральным законом.

Свидетельский иммунитет увеличивает количество прав свидетелей, а также увеличивает их правовую защищённость. Так же это является способом борьбы с лжесвидетельством. Следует заметить, что зачастую сожители либо лица, не являющиеся близкими родственниками не имеющие свидетельского иммунитета, могут быть ближе, чем близкие родственники. Именно поэтому такие вещи не могут быть установлены законом. Суд должен учитывать обстоятельства каждого дела.

Нельзя забывать о том, что хоть свидетельские показания зачастую бывают весьма полезны и важны, главной проблемой их использования все же остается недостоверность полученной информации. В настоящее время ведутся работы над усовершенствованием порядка использования свидетельских показаний и пресечения возможности извлечения лжи из них. К примеру выявлено, что дача ложных показаний зачастую это осознанный шаг, а принятие такого решения происходит под воздействием эмоционального напряжения.

Поэтому работа со свидетелями - это большой труд. Решить все задачи в рамках процесса довольно сложно в силу следующего:

\section{- ограниченных временных рамок;}

возможности проверки правдивости показаний средствами, которыми располагают субъекты доказывания и судья по материалам данного дела.

В судебной практике свидетель вызывается в суд для того, чтобы подтвердить какоето зафиксированное в деле обстоятельство. Поэтому допрос свидетеля в процессе обычно занимает $10-15$ минут.

Но существует некоторые способы, которые помогают понять где были даны ложные показания. Многие юристы считают, что использование противоречий, существующих между свидетельскими показаниями и другими доказательствами помогут докопаться до истины. Существует даже такое интересное предложение Л.А. Смолиной. Она предлагает ввести в гражданский процесс очную ставку, что в свою очередь облегчит работу суда. С другой же стороны нужно не забывать, что при проведении допросов свидетель должен чувствовать себя защищенно и в безопасности. Но следует отметить, что имеется необходимость совершенствования правого регулирования этого института.

Подводя итоги изучения особенностей и проблем дачи свидетельских показаний необходимо отметить, что не нужно ими пользоваться как единой истиной. Человек вполне мог сбиться в собственных мыслях, путаются и забываются воспоминания. Так же всегда существует возможность того, что свидетель намеренно вводит суд и весь процесс в заблуждение, так как проблема лжесвидетельства до сих пор не решена. Поэтому к данному виду доказательств нужно подходить с особым вниманием и осторожностью. Не нужно забывать, что показания свидетелей не заменят письменных доказательств.

$$
* * *
$$

1. Гражданский процессуальный кодекс Российской Федерации «Гражданский процессуальный кодекс Российской Федерации» от 14.11.2002 г. N 138-ФЗ (в ред. от 01.07.2021) // С3 РФ. 2002. N 46 Ст. 4532. 
2. Дрожжин В. Правосудие в Древнем Риме // Российская юстиция. - 1994. - № 10. - С. 34

3. Российская Федерация. Законы. Конституция Российской Федерации [принята всенародным голосованием 12.12.1993 г.] // СПС «КонсультантПлюс».

4. Закатов А. А. Ложь и борьба с нею. - Волгоград, 1984. - С. 46-47

5. Смолина Л. А. Очная ставка в гражданском процессе. Проблемы судопроизводства по делам, возникающим из гражданских и административных правоотношений // Сборник статей по материалам международной научно-практической конференции. Северо-Западный филиал ФГБОУВО «Российский государственный университет правосудия». - 2017. - С. 225-229.

6. Петров, И. В. Новеллы гражданского кодекса России по обеспечению исполнения обязательств / И. В. Петров, И. И. Дементеева // Актуальные проблемы реформирования гражданского и предпринимательского права : Материалы Всероссийской очно-заочной научно-практической конференции с иностранным участием, Краснодар, 02-03 октября 2015 года / СКФ ФГБОУВО «Российский государственный университет правосудия». - Краснодар: Общество с ограниченной ответственностью "Издательский Дом - Юг", 2015. С. $35-42$.

7. Петров, И. В. Социально-правовая ответственность в предпринимательской деятельности / И. В. Петров, И. И. Дементеева // Национальные экономики в условиях глобальных и локальных трансформаций : Сборник статей международной научно-практической конференции, Москва, 23-28 октября 2018 года / Под ред. Г.Б. Клейнера, Х.А. Константиниди, В.В. Сорокожердьева. - Москва: АНО "Научно-исследовательский институт истории, экономики и права", 2018. - С. 77-80.

\section{Кирушин К.Р., Хисматов Р.С. Эволюция советской судебной системы на примере уголовных дел Набережночелнинского городского суда}

Набережночелнинский государственный педагогический университет (Россия, Набережные Челны)

doi: 10.18411/trnio-01-2022-174

\section{Аннотация}

Данная работа рассматривает процесс становления и развития судебной практики в Советском Союзе во второй половине XX века. Описана история трансформации судебной системы Советского Союза. Рассмотрена проблематика позднесоветской судебной практики и судоустройства на Всесоюзном и региональном уровне.

Ключевые слова: Советский Союз, судебная практика, уголовное дело, суд, судоустройство.

\section{Abstract}

This work examines the process of formation and development of judicial practice in the Soviet Union in the second half of the XX century. The history of the transformation of the judicial system of the Soviet Union is described. The problems of late Soviet judicial practice and judicial system at the All-Union and regional levels are considered.

Keywords: Soviet Union, judicial practice, criminal case, court, judicial system.

Актуальность научной работы заключается в изучении советской судебной системы во второй половине существования Советского государства. Основной упор делается на изучении судебной практике в регионе. Есть множество научных и публицистических работ, касательно судебного обоснования политических репрессий в Советском Союзе, особенностей судебного рассмотрения резонансных уголовных дел, особенностей советского судопроизводства, в нашей работе акцент сделан на уголовных делах, которые в большей степени отражают повседневность советского общества, взаимодействие общества и государства.

Первый этап истории советской судебной системы начался с декрета Совета Народных Комиссаров от 22 ноября 1917 года «О суде» № 1. Согласно декрету: учреждались народные суды в составе постоянного судьи и 2 народных заседателей, которые сменяли дореволюционные мировые суды; вводилось выборность судейского корпуса; допускалось 